УДК 7.025 https://doi.org/10.24852/2587-6112.2021.6.292.301

\title{
ИССЛЕДОВАНИЕ И РЕСТАВРАЦИЯ ТКАНОГО ПОЛОТНА С ЖИВОПИСНЫМ ИЗОБРАЖЕНИЕМ ИЗ ФОНДОВ ГИАХМЗ «ОСТРОВ-ГРАД СВИЯЖСК»
}

\author{
(C) 2021 г. А.С. Лисина, Н.В. Ковязина, Е.В. Колесникова
}

Статья посвящена предмету, который был найден под половицами дома в с. Свияжск в 2018 г. В процессе изучения памятник был идентифицирован как одеяло с живописным слоем, также была установлена его принадлежность, время изготовления и прототип росписи. В статье рассматриваются основные этапы реставрационных работ и предреставрационные исследования памятника. Реставраторы сочетали методы и материалы, применяемые в реставрации масляной живописи и в реставрации текстиля.

Ключевые слова: реставрация текстиля, консервация масляной живописи, предреставрационные исследования, Свияжск, тканое полотно, Ханс Зацка.

\section{STUDY AND RESTORATION OF WOVEN FABRIC WITH A PICTORIAL IMAGE FROM THE COLLECTION OF THE STATE HISTORICAL- ARCHITECTURAL AND ART MUSEUM "THE ISLAND TOWN OF SVIYAZHSK"}

\section{A.S. Lisina, N.V. Kovyazina, E.V. Kolesnikova}

The paper examines an object that was found under the floorboards of a Sviyazhsk house in 2018. During the study, the object was identified as a blanket with a painted layer; the affiliation, time of manufacture and prototype of the painting were also attributed. The paper discusses the main stages of restoration work and pre-restoration studies. The restorers combined methods and materials commonly used in the restoration of oil paintings and textile.

Keywords: textile restoration, oil painting restoration, pre-restoration studies, Sviyazhsk, woven fabric, Hans Zatzka.

Во время реставрационно-ремонтных работ в деревянном доме в с. Свияжск на ул. Александровская директором музея Артемом Николаевичем Силкиным был обнаружен предмет, свернутый в рулон. После осмотра он оказался декоративным полотном - расписным одеялом 1950-х гг. В результате интервьюирования местных жителей было выяснено, что предмет принадлежал Антонине Алексеевне Матвеевой. Одеяло было расписано казанским художником. Первоначальным прообразом послужила работа австрийского художника Ханса Зацки «Девушки у озера» (рис. 1). Эта работа датируется 1920-ми гг.

Тканое полотно с живописным изображением поступило в реставрационный отдел музея-заповедника в 2018 г. Работы проводились под руководством художникареставратора 1 категории Екатерины Владимировны Колесниковой из Вологодского филиала ВХНРЦ. Работы выполняли реставраторы музея Наина Владимировна Ковязина и Анастасия Сергеевна Лисина.
Памятник, поступивший на реставрацию, представляет собой прямоугольное полотно (размеры 184x125 см), на лицевой стороне которого изображены три девушки у озера (рис. 2). В процессе бытования предмет висел на стене, на что указывает наличие крепежных петель по верхнему краю. Из-за большой нагрузки, особенно когда полотно находилось в вертикальном положении, на поверхности стала наблюдаться деформация основы памятника в местах его провисания. Также на сохранность памятника повлияло то, что он длительное время хранился в свернутом виде. Появились значительные разрывы (рис. 3) и осыпи красочного слоя.

Памятник поступил на реставрацию с общей стойкой деформацией основы полотна. Края были неровные, посечённые, пересушенные, ломкие, наблюдалось отставание нитей и мелкие утраты полотна. С оборотной стороны наблюдалось общее запыление и общие стойкие загрязнения в виде неравномерно распределённых пятен и потёков различных цветов 


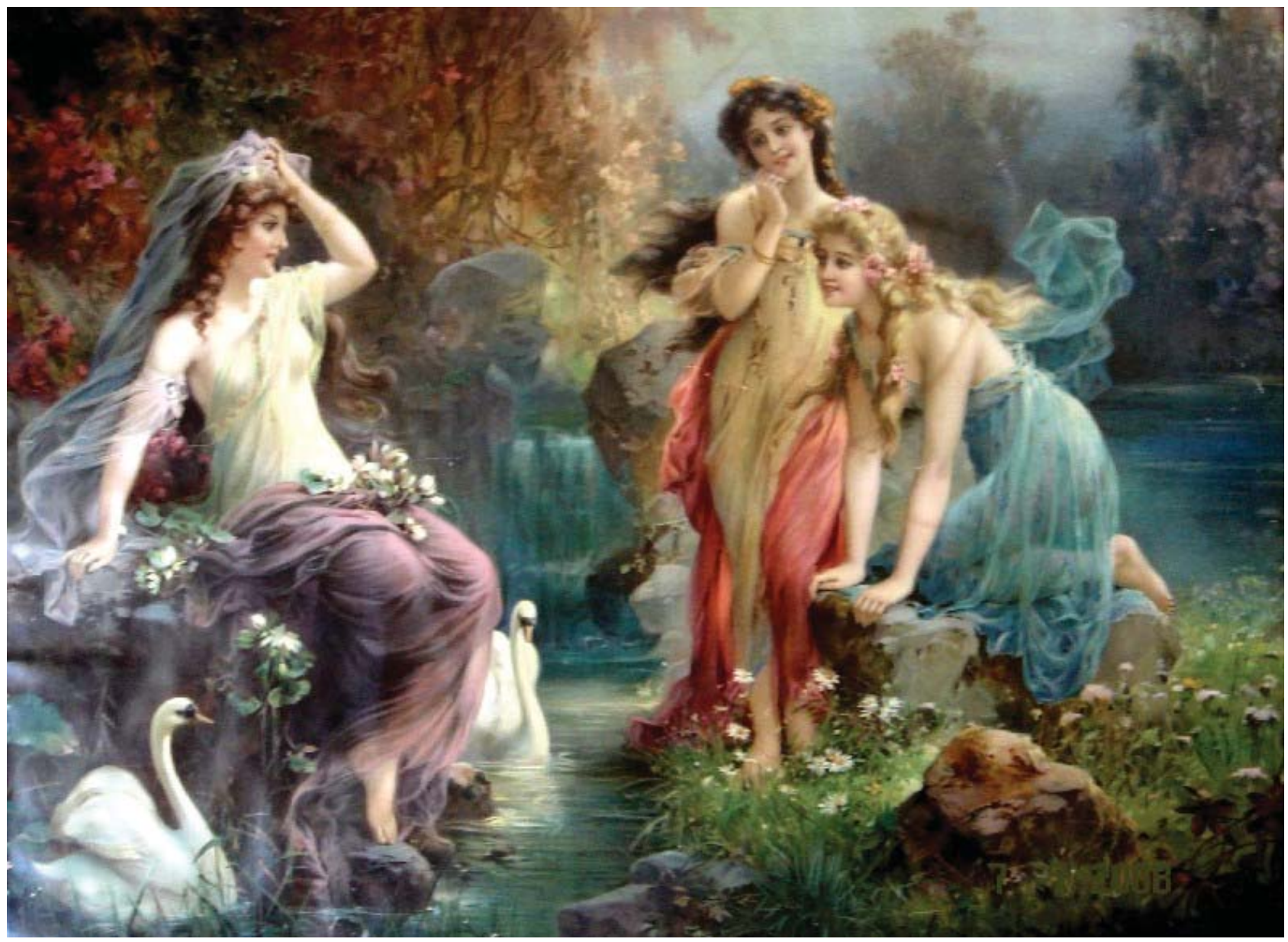

Рис. 1 Ханс Зацка «Девушки у озера».

Fig. 1 Hans Zatzka. "Girls by the lake".

и биогенные следы. На оборотной стороне имелись следы голубой краски в форме объемных потеков, пятен неправильной формы и, в местах наиболее крупных разрывов, в форме неаккуратных продольных мазков (рис. 4). По нижнему краю наблюдалась полоса краски коричневого цвета. Вокруг крепёжных отверстий имелись наслоения рыжего цвета (предположительно продукты коррозии железа).

Красочный слой на лицевой стороне памятника был тонкий; наблюдалось равномерное растрескивание, мелкие локальные участки осыпей (рис. 5). На поверхности лицевой стороны также было общее запыление и общие стойкие жиро-пылевые загрязнения различных цветов, неравномерно распределённые пятна рыхлых белых отложений, биогенные следы, в т.ч. паутина, останки «яиц» и тел насекомых; небольшое пятно, предположительно, клея серо-желтого цвета.

Работы начались с проведения предреставрационных мероприятий. Исследования перед началом реставрационных работ дают возможность правильного подбора реставрационных методик и используемых материалов. Подобный подбор осуществляется индивидуально для каждого памятника, потому что реакция на те или иные материалы или методы работы может быть разной. В данном случае дополнительную сложность в выбор методик вносила неоднозначность классификации памятника - одновременно текстильного и живописного, т.к. основа памятника была изготовлена из нетрадиционного для станковой живописи материала. Серьезной проблемой также является использование различных материалов в реставрации и их совместимость. С целью предотвращения этой проблемы и важно проведение предреставрационных исследований.

Используемые на данный момент методы предреставрационного исследования памятника принято делить на две основные группы: методы, не требующие изъятия какихлибо проб, называемые неразрушающими, неконтактными, неинвазивными, и методы, 


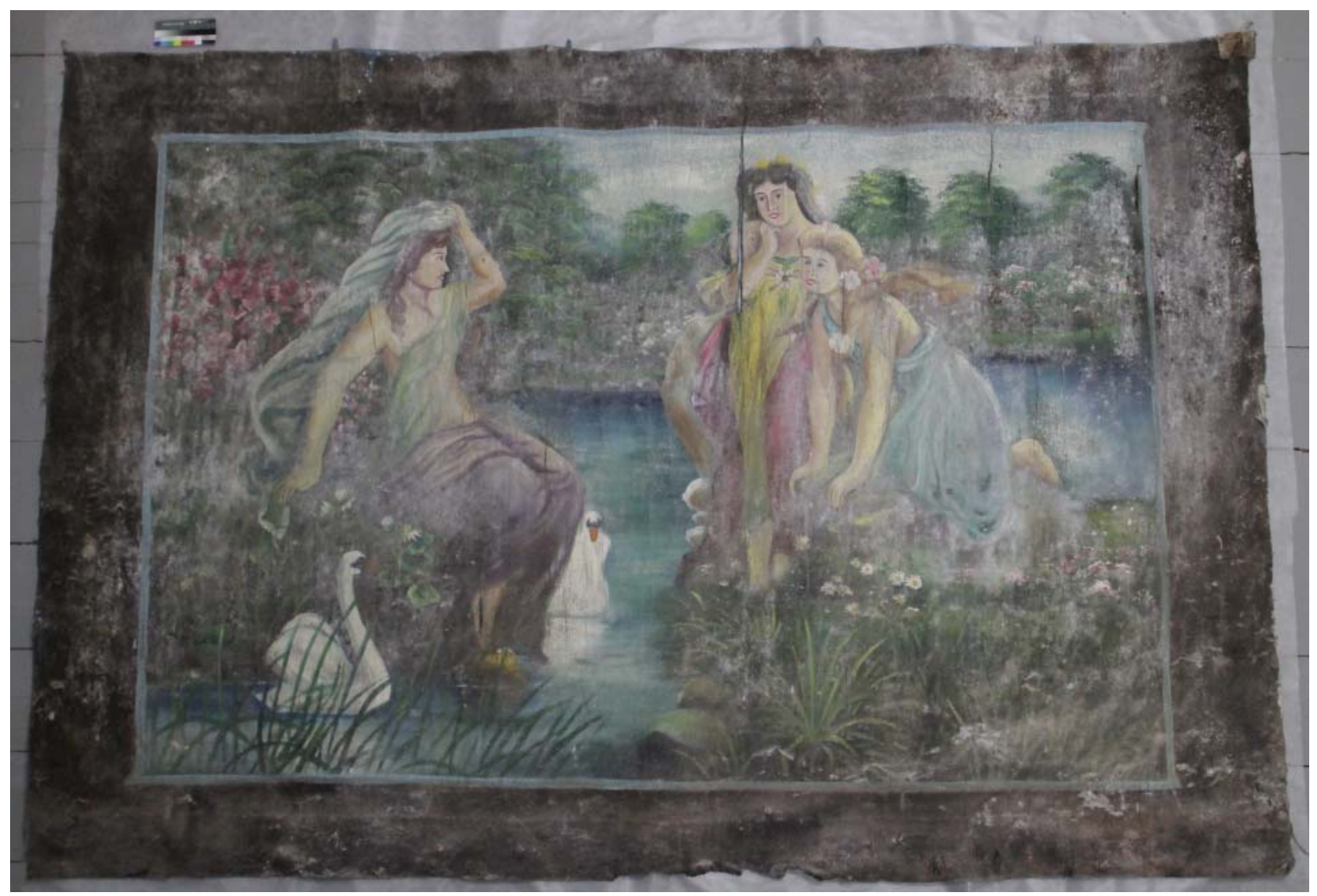

Рис. 2 Тканое полотно с живописным изображением до реставрации. Общий вид. Лицевая сторона.

Fig. 2 Woven textile with a pictorial image before restoration. General view. Front side.

связанные с изъятием пробы, называемые разрушающими, контактными и инвазивными (Фролов, 2018, с. 176). При исследовании тканого полотна были использованы методы, как требующие изъятия проб (инвазивные), так и неинвазивные.

При работе с предметом в первую очередь была определена природа волокна памятника. Целью исследования было определение выбора и способа очистки текстиля и способов его укрепления. Исследование проводилось с помощью микроскопа Leica M60 с камерой Leica IC90 Е. Были взяты пробы нитей во взаимно-перпендикулярных направлениях. В микроскоп наблюдалась веретенообразная форма волокна с поперечными складочками (рис. 6: а, б). Результат: нити полотна по утку и по основе - лён. (Кирюхин, 2011, с. 78).

На поверхности полотна, как с лицевой, так и с оборотной стороны присутствовали белые рыхлые загрязнения неизвестного происхождения. Было выдвинуто предположение о том, что данные загрязнения могут быть хлоридами (Cl-) и сигнализировать об опасной засоленности памятника, карбонатами кальция
$\left(\mathrm{CaCO}_{3}\right)$ либо же сульфатными солями гипса $\left(\mathrm{CaSO}_{4} * 2 \mathrm{H}_{2} \mathrm{O}\right)$ и появиться на памятнике вследствие его продолжительного контакта с материалами отделки стен. Чтобы исключить или подтвердить предполагаемую природу загрязнений, было принято решение о проведении микрохимического анализа с взятием проб при помощи скальпеля. Микрохимические пробы были проведены с использованием 20\% водного раствора соляной кислоты $(\mathrm{HCl}), 10 \%$ водного раствора хлористого бария $\left(\mathrm{BaCl}_{2}\right)$ и $0.1 \%$ раствора нитрата серебра $\left(\mathrm{AgNO}_{3}, 0,1\right.$ н раствор). Более подробно методика проведения исследований описана в методических рекомендациях Л.Н. Андреевой (Реставрация музейной керамики..., 1999 , c. 34-35, с. 44-45). Результаты проб - хлориды, карбонаты кальция и сульфатные соли гипса в составе указанных загрязнений отсутствуют. Исходя из этого, необходимость проведения обессоливания предмета не подтвердилась.

Далее памятник был изучен под ультрафиолетовыми лучами. Проведено исследование при помощи прибора люминесцентной диагностики Вуда В-221. Результат исследова- 


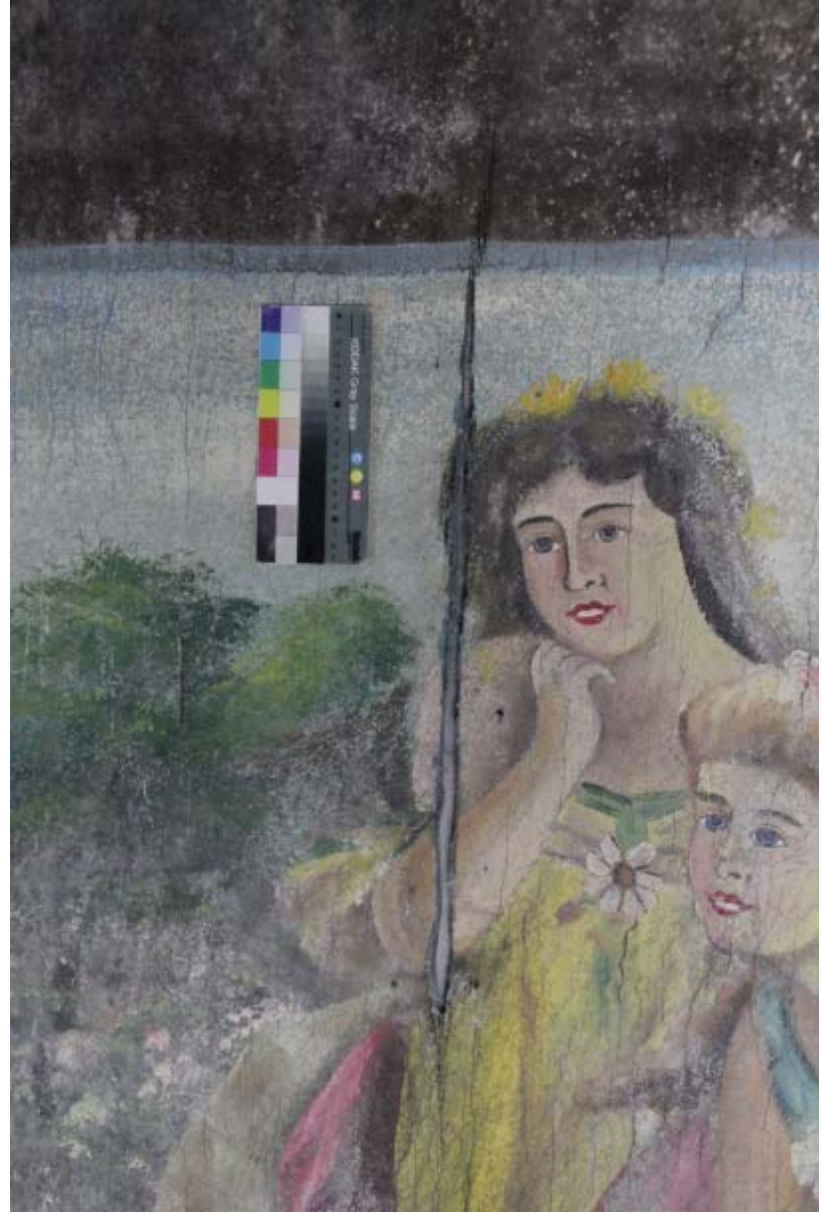

ния показал, что на памятнике свечение активной плесени не наблюдалось, следовательно, присутствие живой плесени не было обнаружено. Данный результат отбросил предполагаемое проведение фунгицидной обработки памятника. Также в результате было выявлено опалесцирующее свечение на серо-желтом пятне, что говорит о том, что это пятно клея (Гренберг, 1987, с. 53).

Одним из важных этапов в реставрации любого материала является очистка. Выбор материалов и способов очистки опирается на устойчивость к ним составляющих памятника. Пробы на устойчивость красочного слоя, к выбранному методу очистки проводились методом тампонирования с помощью ватных тампонов, смоченных:

1. Дистиллированной водой: красочный слой основного полотна и коричневый слой рамки по периметру - устойчивы к воздействию.

2. Пеной мыльного раствора детского мыла:

a) красочный слой основного полотна устойчивы.
Рис. 3 Фрагмент (разрыв) до реставрации. Лицевая сторона.

Fig. 3 Fragment (tear) before restoration. Front side.

б) коричневая краска - не значительно устойчива.

В результате было принято решение о проведении водной очистки с использованием поверхностно-активных веществ с низким уровнем щелочности, отбеливающих и флюоресцирующих веществ (Кумпан, Камалетдинова, 2014, с. 98). Использование моющего средства позволяет понизить поверхностное натяжение на границе вода очищаемая поверхность и способствует более глубокому проникновению воды в капилляры загрязненной поверхности. Использование моющего средства представляет собой процесс солюбилизации (растворения) органических веществ внутри мицелл, которые в достаточном количестве присутствуют в растворах мыл (Яброва, 1976, с. 186).

На оборотной стороне памятника были выявлены многочисленные пятна голубой краски по местам разрывов и по периметру полотна. Для устранения деформации полотна требовалось удаление этих загрязнений. Для этого были проведены пробы с целью подбора растворителей. Пробы проводились методом наложения ватных компрессов (5 мин.), смоченных:

Дистиллированной водой - материалы красочных загрязнений набухают и размягчаются.

Этиловым спиртом - реакция отсутствует. Однако было выяснено, что на этиловый спирт реагирует краска коричневого цвета на лицевой стороне предмета. Материалы красочного слоя реагируют окрашиванием тампона в розовый цвет.

3. Уайт-спиритом - материалы красочных загрязнений набухают и размягчаются.

В результате было принято решение об удалении пятен голубой краски механически с использование ватных компрессов дистиллированной воды.

Утверждённый на научно-реставрационном совете план мероприятий состоял в очистке памятника, устранении деформации, заделке разрывов, укреплении красочного 


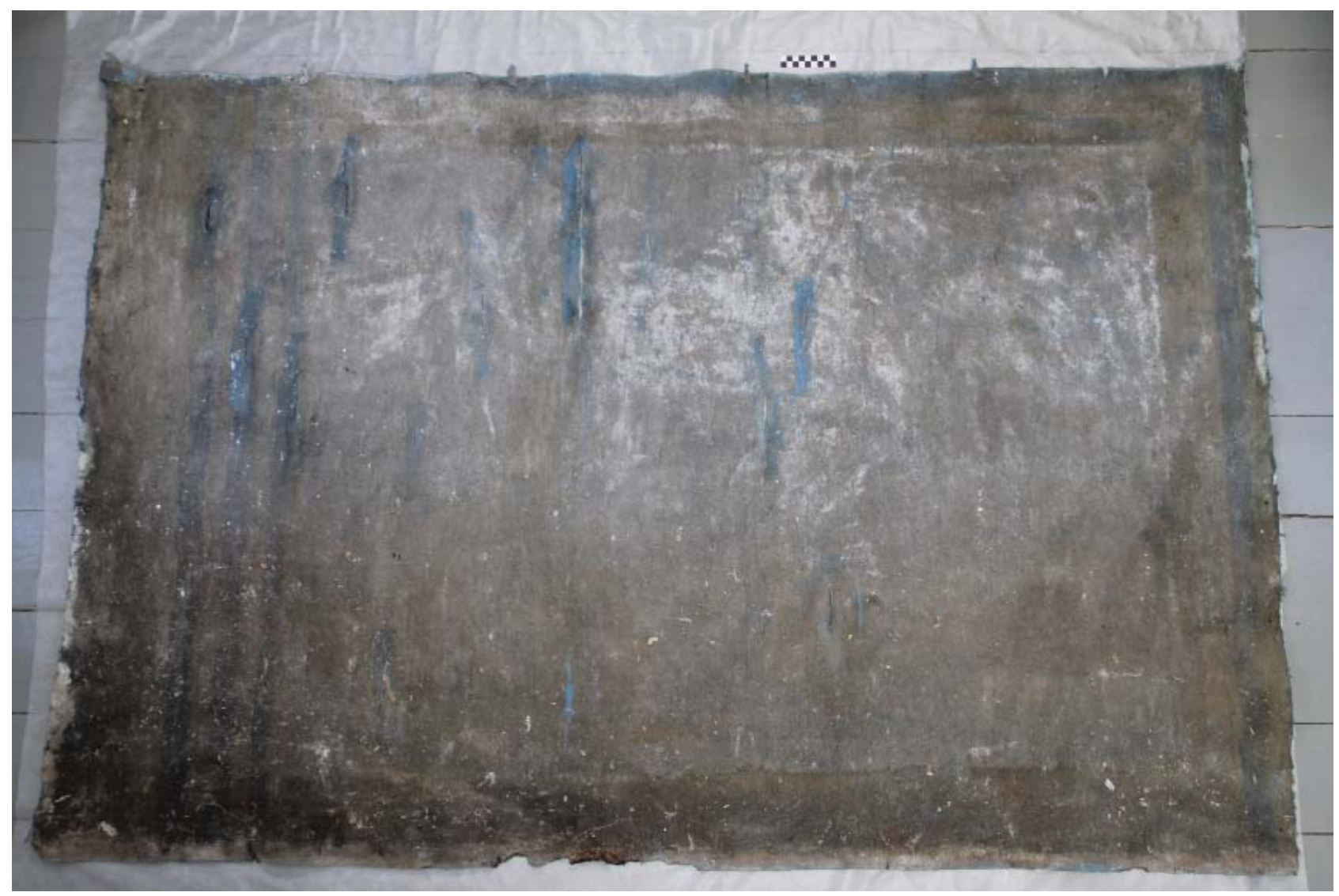

Рис. 4 Тканое полотно с живописным изображением до реставрации. Общий вид. Оборотная сторона.

Fig. 4 Woven textile with a pictorial image before restoration. General view. Reverse side.

слоя и выборе способа хранения и экспонирования предмета.

Реставрация живописи предполагает в первую очередь укрепление красочного слоя, дублировку и подведение реставрационного грунта и пр. и только потом удаление загрязнений (Горин, 1977, с. 138). Нами был выбран иной порядок по той причине, что на предмете были значительные загрязнения, в том числе с биогенными следами. Также реставрация полимерных материалов натурального происхождения в первую очередь подразумевает устранение загрязнений, очистку поверхности (Кумпан, Камалетдинова, 2014, с. 98). При таком порядке действий сохранность красочного слоя в связи с осыпаниями и кракелюром не подвергалась риску.

Прежде всего, необходимо было удалить загрязнения с поверхности предмета. Работы начались с механической очистки обеих сторон памятника различными способами. На оборотной стороне работы велись с использованием скальпеля и деревянного стека, ими удалялись стойкие загрязнения, затем поверхность была обеспылена с применением музейного пылесоса (соответственно, к оборотной стороне были применены адаптированные к наличию красочного слоя методики из реставрации текстиля). Механическая очистка лицевой стороны проводилась последовательно, небольшими участками с помощью мягких кистей (щетина и синтетика). После этого было проведено механическое удаление затеков голубой и коричневой краски на оборотной стороне памятника с ватными компрессами дистиллированной воды.

Далее следовала поверхностная очистка лицевой стороны от загрязнений. Вся поверхность памятника была очищена водным способом с применением моющего средства и дистиллированной воды (Кумпан, Камалетдинова, 2014, с. 98). Очистка выполнялась методом прокатывания тщательно отжатыми тампонами, смоченными в $3 \%$ мыльном растворе. Затем следовала многократная промывка очищаемых участков дистиллированной водой и удаление остатков влаги с помощью фильтровальной бумаги. Остатки моющего средства необходимо удалять по той причине, что, оставаясь адсорбированными на чистой поверхности, с течением времени они могут отрицательно повлиять на сохранность живо- 


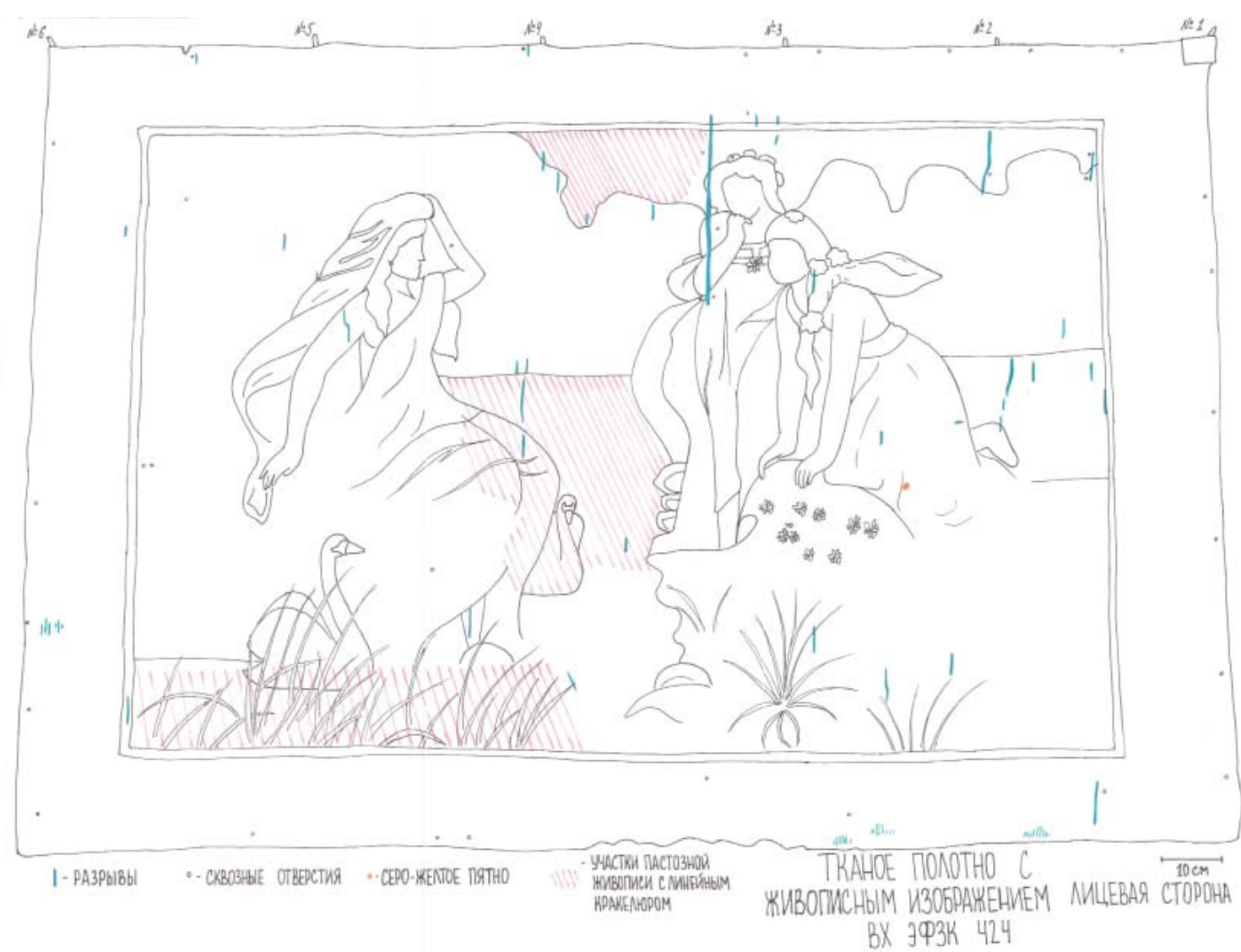

Рис. 5 Картограмма сохранности лицевой стороны.

Fig. 5 Front side preservation diagram.

писного слоя (Яброва, 1976, с. 186). Указанная методика относится к реставрации живописи.

После этого было проведено устранение деформаций основы. Общая деформация была исправлена при помощи холодных прессов. Участки более стойкой деформации исправлялись локально, с помощью музейного реставрационного утюга и прессов (Горин, 1977, с. 84). Места деформаций увлажнялись дистиллированной водой из пульверизатора. Затем проглаживались через двойную хлопчатобумажную ткань электроутюгом при температуре $60^{\circ} \mathrm{C}$. После этого на места разрывов устанавливался холодный пресс на срок 1-3 дня (в зависимости от стойкости деформаций). Данный метод можно назвать в определённой степени общим для реставрации живописи и текстиля. Устранение деформаций заняло достаточно много времени, но для нас важно было получить ровную поверхность, чтобы в дальнейшем работать с разрывами.

Разрывы по своей конфигурации и размерам были различными: угловыми, ступенчатыми, округлыми. В практике реставрации живописи очень распространена заделка разрывов методом наложения заплат (Горин,
1977, с. 97). Однако такой метод имеет значительный минус - любая по толщине заплата вызовет выпуклость с лицевой стороны, что было нежелательно, учитывая размер и вес памятника, а так же состояние красочного слоя. Поэтому была выбрана заделка разрывов методом «встык». Склеивание сквозных разрывов проводилось на $10 \%$ раствор PVB в этаноле (Федосеева, 2016, с. 90). Поливинилбутираль обладает высокой вязкостью и низкой проникающей способностью, что было важно в процессе заделки разрывов и не допущении прохода клея на лицевую сторону. Работы по склеиванию разрывов начинались на оборотной стороне. С торцевой части разрывы при помощи синтетической кисти были пропитаны клеем. Ширина проклейки каждого края составляла 2 мм. Клей был доведен до состояния отлипа, после чего края были сведены и плотно соединены. Нити разрыва были расправлены, подобраны, проклеены и вставлены на свои места. Затем нити были прижаты шпателем. В случаях утраты нитей по местам разрывов, вживались дополнительные, ранее окрашенные, нити льна, подобранные по толщине к оригинальным нитям. Нити 

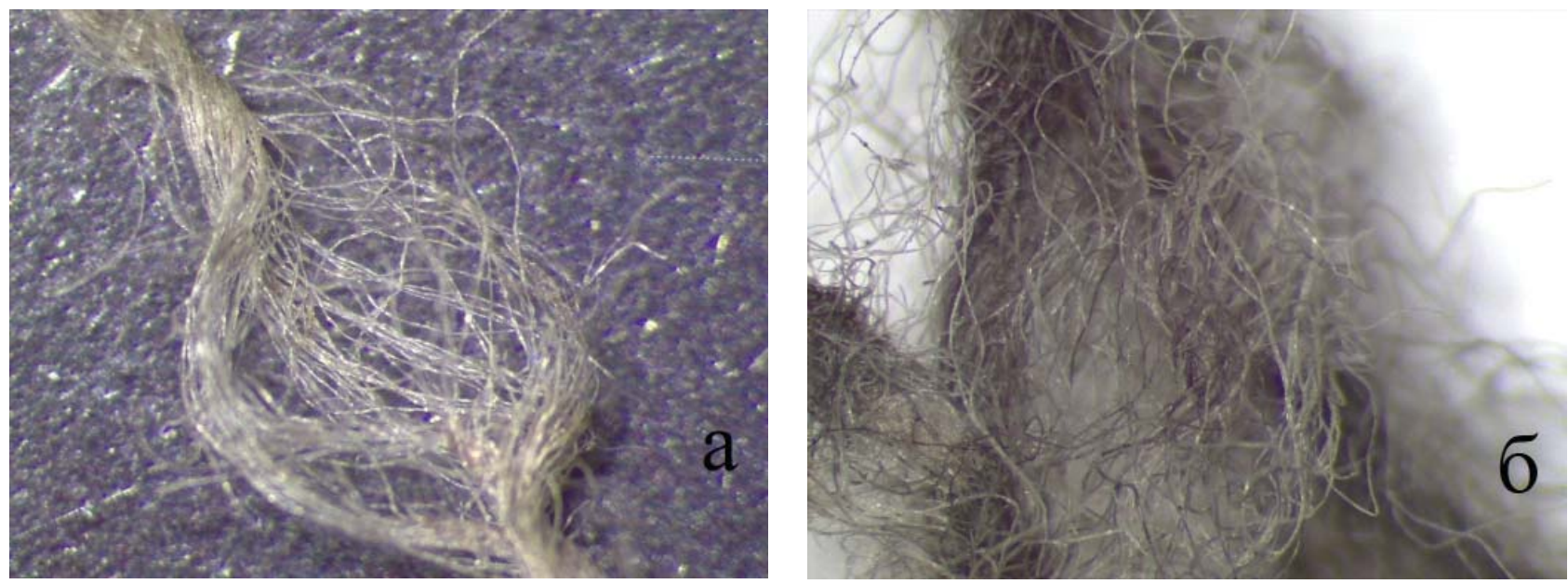

Рис. 6 Микросъёмка нитей: a - основы, б - утка.

Fig. 6 Microphotograph of the threads: a - Warp, b - Abb.

были окрашены по методике, описанной в работе Е.В. Семечкиной (Семечкина, 1990). В местах, где имелись незначительные утраты, проколы, разрывы, вставлялся растрепанный скальпелем пух нитей. Клей наносился на края утрат, после неполного подсыхания утраты заполнялись при помощи зонда пухом, пропитанным клеем. После этого места разрывов через фторопластовую подложку проглаживались термошпателем при температуре $50^{\circ} \mathrm{C}$. Аналогичная работа проводилась на лицевой стороне. После на разрыв помещался холодный пресс (фторопластовая подложка, сукно, мраморная плитка). Процесс прессования одного разрыва длился сутки (Горин, 1977, с. 98).

В работе с большим разрывом (рис. 3) была применена следующая технология. В края разрыва во взаимно-перпендикулярных направлениях вживлялись льняные нити, подобные нитям основы и утка. Концы нитей проклеивались $10 \%$ раствором PVB в этаноле и при помощи зонда вставлялись в края разрыва на ширину 2 мм. После этого вживленные, приклеенные нити основы и утка переплетались между собой, повторяя полотняное переплетение основы полотна, после конец нити основы вживлялся с другой стороны края разрыва. По окончанию переплетения нитей, полученная заплатка была пропитана $10 \%$ раствором PVB в этаноле, проглажена термошпателем через фторопластовую подложку, после был поставлен холодный пресс на сутки. Затем повторно вживлялись нити утка вровень с авторским холстом, проклеивались 10 \% раствором PVB в этаноле с последующим проглаживанием через фторопласто- вую подложку термошапателем и установкой холодного пресса на 3 дня (Горин, 1977, с. 99).

Только после заделки разрывов мы смогли приступить к локальному укреплению красочного слоя. Под понятием укрепление красочного слоя понимается восстановление связи с холстом и одновременное укладывание деформированных участков (Горин, 1977, с. 103). Нами была применена методика пропитки по местам растрескивания красочного слоя водным раствором акриловой дисперсии клея Lascaux Acrylkleber 498-20X (1:1) с кисти (Федосеева, 2016, с. 96-98). После проводилась фиксация красочного слоя электроутюгом при температуре $50{ }^{\circ} \mathrm{C}$ через фторопластовую подложку. Затем на сутки устанавливался холодный пресс (Бобров, 2008, с.93).

Когда были выполнены основные работы с памятником, встал вопрос о его хранении и экспонировании. Нередкими бывают случаи хранения большемерных произведений живописи накатанными на валы (Гурулева, 2012, с. 15). Такое хранение может иметь временный характер, так как холсты со временем неизбежно деформируются и возможно повреждение красочного слоя. Несмотря на то, что все разрывы были укреплены, как и красочный слой, сохранность предмета не позволяла такое хранение памятника. На научно-реставрационном совете было принято решение об изготовлении планшета и о дальнейшем натягивании памятника с подведенными кромками на планшет (Горин, 1977, с. 206). Также было принято решение демонтировать петли и заплатку, так как они потеряли свою функциональность и давали дополнительную деформацию экспонату. Для дублирования 


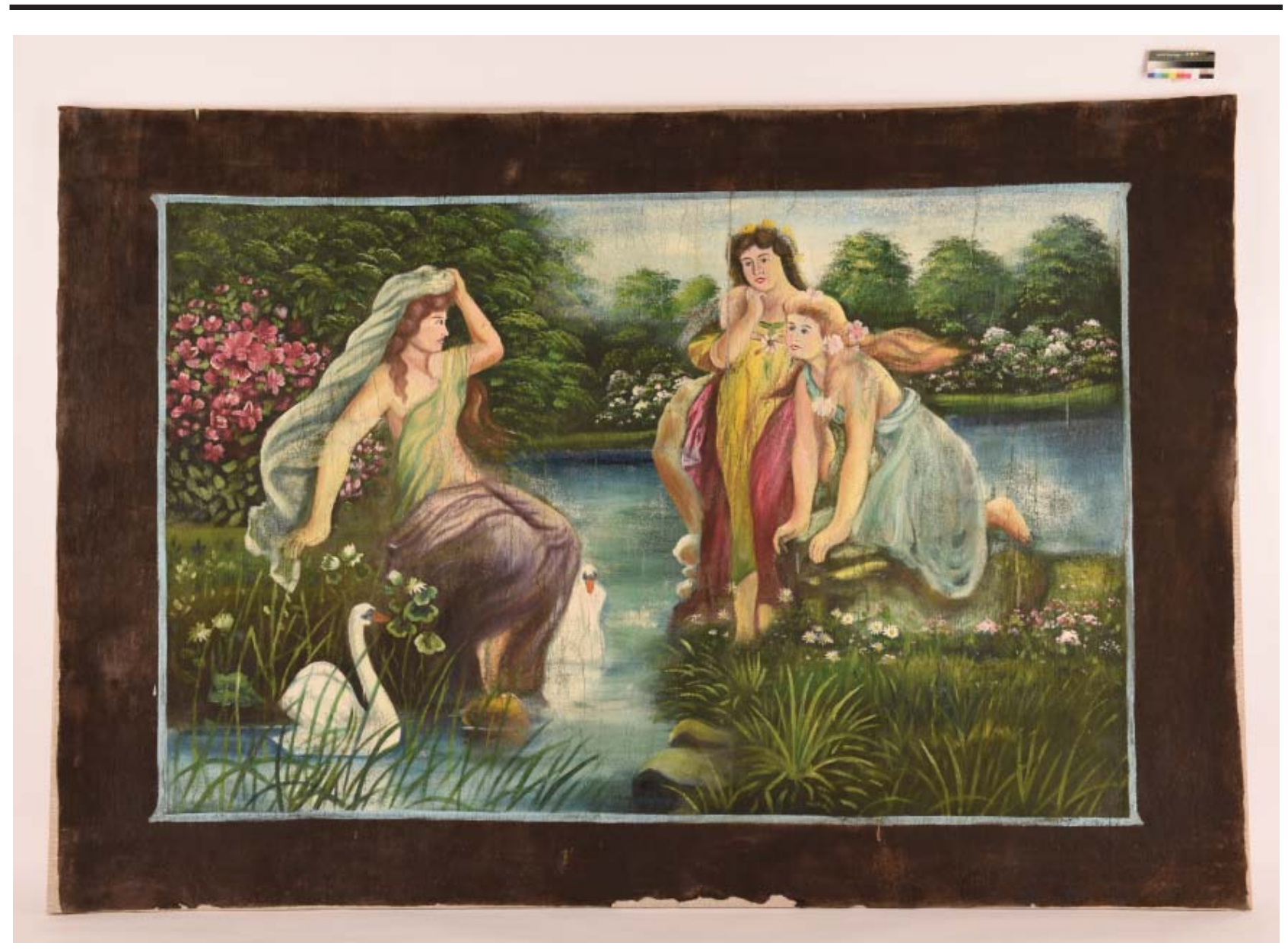

Рис. 7 Тканое полотно с живописным изображением после реставрации. Общий вид. Лицевая сторона.

Fig. 7 Woven textile with a pictorial image after restoration. General view. Front side.

кромок была использована льняная ткань. Ширина дублировочных кромок складывается из толщины бруска подрамника, величины захода холста под живопись и размера холста, необходимого для загиба и заделки на оборотной стороне подрамника (Горин, 1977, c. 93). Заход холста на основное полотно был 4 см. На кромки с кисти наносилась акриловая дисперсия Lascaux Acrylkleber 498-20X (Кобякова, 2014, с. 187). Важными требованиями к адгезиву были надёжное склеивание без проникновения в нити холста и не провоцированием усадки. (Федосеева, 2016, с. 99). Дублирование кромок проводилось с помощью проглаживания валиком, фторопластовым шпателем и с последующей термофиксацией электроутюгом при температуре $50{ }^{\circ} \mathrm{C}$ через хлопчатобумажную ткань.

В результате реставрации была проведена сложная многоэтапная механическая очистка памятника с двух сторон, поверхностная очистка красочного слоя, убраны затеки голубой краски. Заделаны разрывы и укреплен красочный слой, а также устранена сложная деформация. Натяжка памятника на планшет дает возможность избежать в дальнейшем его деформации, а также дополнительное укрепление и поддержку (рис. 7). В результате проведения реставрационных работ начавшиеся процессы разрушения предмета были приостановлены. Предмет приобрел надлежащий вид для хранения и экспонирования. В настоящее время предмет хранится в фондах ГИАХМЗ «Остров-град Свияжск».

Данная работа была интересна тем, что для её проведения необходимо было решить задачу сочетания методологий реставрации разных материалов: использовать приёмы и материалы, применяемые в реставрации масляной живописи и реставрации текстиля. Выбор методов реставрации и консервации необходимо корректировать в каждом отдельном случае, с учётом особенностей сохранности каждого предмета. Адаптация методик, составление и воплощение нетипичного плана реставрационных мероприятий непростая и часто возникающая задача как в реставрации этнографических, так и в рестав- 
рации археологических предметов. Поэтому ботки методик необходимо разделять с научопыт совмещения и индивидуальной разра-

ным реставрационным сообществом.

\section{ЛИТЕРАТУРА}

Белов С.Г., Коршунова О.Н. Пороховое производство в Казанском крае: к истории формирования химической промышленности на территории Татарстана (вторая половина XVI - первая половина XVIII вв.) // Вестник Казанского технологического университета. 2014. Т. 17. № 9. С. 337-339.

Реставрация музейной керамики: методические рекомендации / Отв. ред. Л.Н. Андреева. М.: ВХНРЦ им. академика И.Э. Грабаря, 1999. 144 с.

Бобров Ю.Г., Бобров Ф.Ю. Консервация и реставрация станковой темперной живописи. М.: Художественно-педагогическое издательство, 2008. 128 с.

Горин. И.П., Черкасова 3.В. Реставрация произведений станковой масляной живописи. М.: Искусство, 1977. $223 \mathrm{c.}$

Гренберг Ю.И. Технология и исследование произведений станковой и настенной живописи. М.: Изобразительное искусство, 1987. 392 с.

Гурулева М.В. Станковая живопись на валах в Государственном Эрмитаже // Проблемы реставрации памятников культуры и искусства. Екатеринбург. 2012. С. 15 - 20.

Кирюхин С.М., Шустов Ю.С. Текстильное материаловедение. М.: КолосС, 2011. 360 с.

Кобякова В.И., Лобова Л.В. Сравнительная оценка свойств адгезивов, применяемых при реставрации знамен и других музейных предметов из тканей // Консервация, реставрация и экспонирование памятников военной истории / Отв. ред. С.В. Успенская, В.И. Кобякова. СПб.: ВИМАИВиВС, 2014. С. 185-200.

Косолапов А.А. Естественнонаучные методы в экспертизе произведений искусства. СПб: Издательство Государственного Эрмитажа, 2015. 222 с.

Кумпан Е.В., Камалетдинова А.И. Анализ основных методов очистки при реставрации музейных полимерных материалов натурального происхождения // Вестник Казанского технологического университета. 2014. Т. 17. №2. С. 98-100.

Семечкина E.B. Реставрация тканей. Крашение текстильных материалов. Методические рекомендации. М.: ВХНРЦ, 1990.

Федосеева Т.С. Реставрационные материалы. М.: Индрик, 2016, 232 с.

Фролов Д.Ю. Неразрушающие методы исследования // Реставрация произведений станковой темперной живописи / Отв.ред. Г.С. Клокова. М.: Изд-во ПСТГУ, 2018. С. 176-181.

Яброва Р.Р. Основные сведения по химии для реставраторов произведений станковой масляной и темперной живописи // Основы музейной консервации и исследования произведений станковой живописи / Отв. ред. Ю.И. Гренберг. М.: Искусство, 1976. С. 176-221.

\section{Информация об авторах:}

Лисина Анастасия Сергеевна, заведующий реставрационным отделом, ГИАХМЗ «Остров - град Свияжск» (с. Свияжск, Россия); 1.a.s.27@mail.ru

Ковязина Наина Владимировна, магистр направления Реставрация историко-культурного наследия (г. Новосибирск, Россия); nainavladimirovna@gmail.com

Колесникова Екатерина Владимировна, художник-реставратор 1 категории, ВХНРЦ им. Академика И.Э. Грабаря, Вологодский филиал (г. Вологда, Россия); shepelevo4ka@mail.ru

\section{REFERENCES}

Gorin, I. P., Cherkasova, Z. V. 1977. Restavratsiia proizvedenii stankovoi maslianoi zhivopisi (Conservation of Easel Oil Paintings). Moscow: "Art" Publ. (in Russian).

Grenberg, Yu. I. 1987. Tekhnologiia i issledovanie proizvedenii stankovoi i nastennoi zhivopisi (Technology and Study of Easel and Wall Paintings). Moscow: "Art" Publ. (in Russian).

Guruleva, M. V. 2012. In Problemy restavratsii pamiatnikov kul'tury i iskusstva (Issues in Conservation of Culture and Art Monuments). Yekaterinburg, 15-20 (in Russian).

Bobrov, Yu. G., Bobrov, F. Yu. 2008. Konservatsiia i restavratsiia stankovoi tempernoi zhivopisi (Conservation and Restoration of Easel Tempera Paintings). Moscow: Artistic and pedagogical publishing house (in Russian). 
Kiryukhin, S. M., Shustov, Yu. S. 2011. Tekstil'noe materialovedenie (Textile Material Science). Moscow: "ColosS" Publ. (in Russian).

Kobyakova, V. I., Lobova, L. V. 2014. In Uspenskaia, S. V., Kobiakova, V. I. (eds.). Konservatsiia, restavratsiia i eksponirovanie pamiatnikov voennoi istorii (Conservation, Restoration and Exhibiting of Military History Monuments). Saint Petersburg, 185-200 (in Russian).

Kosolapov, A. A. 2015. Estestvennonauchnye metody v ekspertize proizvedenii iskusstva (Natural Scientific Methods in Fine Arts Expertise). Saint Petersburg: Publishing House of the State Hermitage (in Russian).

Kumpan, E. V., Kamaletdinova, A. I. 2014. In Vestnik Kazanskogo tekhnologicheskogo universiteta (Bulletin of the Kazan Technological University) 17 (2), 98-100 (in Russian).

Belov, S. G., Korshunova, O. N. 2014. In Vestnik Kazanskogo tekhnologicheskogo universiteta (Bulletin of the Kazan Technological University) 17 (9), 337-339 (in Russian).

Andreeva, L. N. (ed.). 1999. (Restavratsiia muzeinoi keramiki: metodicheskie rekomendatsii (Conservation of Museum Ceramics: Methodical Recommendations). Moscow: All-Russian Art Scientific Restoration Center named after Academician I.E. Grabar (in Russian).

Semechkina, E. V. 1990. Restavratsiia tkanei. Krashenie tekstil'nykh materialov. Metodicheskie rekomendatsii (Conservation of Textiles. Dyeing of Textile Materials. Methodical Recommendations) Moscow: Academician I.E. Grabar All-Russian Art Scientific Restoration Center.

Fedoseeva, T. S. 2016. (Restoration Materials) Conservation materials Moscow: "Indrik" Publ. (in Russian).

Frolov, D. Yu. 2018. In G. S. Klokova (ed.). Nerazrushayushie metody issledovaniya Conservation of Easel Tempera Paintings M.: Orthodox Svyato-Tikhonovskiy Humanitarian University, 176-181 (in Russian).

Yabrova, R. R. 1976. In Grenberg, Yu. I. (ed.). Osnovy muzeinoi konservatsii i issledovaniia proizvedenii stankovoi zhivopisi (Fundamentals of Museum Conservation and Studies of Easel Paintings). Moscow: "Art" Publ., 176-221 (in Russian).

\section{About the Authors:}

Lisina Anastasia S. head of the conservation department of the State Historical Architectural and artistic museum-reserve "The town-island of Sviyazhsk". Moskovskaya, 6, 422520, Sviyazhsk, Russian Federation; 1.a.s.27@mail.ru

Kovyazina Naina V. Master of Arts (Conservation of Historical and Cultural Heritage) (Novosibirsk, Russia); nainavladimirovna@gmail.com

Kolesnikova Ekaterina V. 1st rank conservator, Academician I.E. Grabar All-Russian Art Scientific Restoration Center, Vologda affiliate. Zasodimsky Str., 14a, 160000, Vologda, Russian Federation; shepelevo4ka@mail.ru 